\title{
Exploring the Factors that Determine Flow of Agricultural Credit to Indian States
}

\author{
Abhijit Sinha* and Dipak Kundu ${ }^{* *}$
}

Abstract

The issue of agriculture and agricultural credit has always gained importance in the context of India. The present research looks at various important aspects of agricultural credit which include growth trend and determination of factors that influence flow of credit to the different states. The findings are based on analysis of twenty nine states for the period 2007-08 to 2017-18. The empirical research shows wide disparity across regions with the maximum flow to the southern region and the minimum to the north-east of the country. The study traces the growth in agricultural loans and finds that nature of the curve is in the quadratic form where the rate of decline is much less compared to the rapid rise in the growth of loans in all the regions. With regard to the panel regression model, cropping intensity, lending rate and inflation rate have a significant effect on flow of credit to states (at 1\% level). However, though the share of agriculture in the state GDP matches the expected sign, the coefficient is not significant even at $10 \%$. The study is a unique one which is an improvement over the earlier studies. However, non-availability of data for all states and exclusion of non-financial considerations at the state level are limitations of the study.

Keywords: Agricultural Credit, Trend, Panel Regression, Fixed Effect, Clustered Model

\section{INTRODUCTION}

India is a country in which the contribution to the gross domestic product (GDP) comes from three sectors which are agriculture and allied activities, industry and services. Over time, the contribution of the sectors has experienced a change and we have seen the steady decline of the agricultural sector on the one hand and the steady rise of the services sector on the other. As per the data for 2011-12, the contribution of the three sectors was $14.39 \%, 31.46 \%$, and $54.15 \%$ respectively (Source: statisticstimes.com). However, towards the later part of the decade, there has been a drastic decline in the contribution from the industry sector and a jump for the services sector. As per the CIA Factbook (2017), the contribution from the three sectors was estimated to be $15.4 \%, 23 \%$ and $61.5 \%$ respectively. Apart from the contribution to agriculture, around $47 \%$ of the labour force of the country is engaged in agriculture. In terms of GDP contribution from the agricultural sector, the country has seen a rise from Rs.5009 billion in the third quarter of 2011 to Rs. 6091 billion in the third quarter of 2020 which is a jump of almost $21.6 \%$. In terms of employment, the sector has employed almost $47 \%$ of the total labour force in the country which automatically speaks of its importance in the Indian economy. The Census (2011) report mentions that almost $55 \%$ of the workers are engaged in agricultural and allied activities. However, as per the Labour

\footnotetext{
Associate Professor, Department of Commerce, Vidyasagar University, Midnapore, West Bengal, PIN - 721102

E-mail: abhijitsinha_091279@rediffmail.com (Corresponding author)

** Assistant Professor, Department of Commerce, Bankim Sardar College, West Bengal, India E-mail: dip11091979@gmail.com
} 
Bureau Report (2015-16), the percentage of total employment has come down to 46.1 per cent. In a reference to the globe, India stands at a strong position. With the country engaged in agricultural activity worth $\$ 375.61$ billion, it stands at the second position but is far below that of China which has activities worth $\$ 991$ billion GDP. The empirical data thereby shows the relevance of the agricultural sector in the economy. Hence, growth of this sector is a bare necessity for an economy like ours where a major section of the population relies on the sector for its income and depends on it as the main source of livelihood. NSSO data reveals that credit forms the key support of such households. However, it is sad to know that even today, a huge section of such households rely on the informal sector (local moneylenders) for such credit support. This condition prevails despite efforts made under the Reserve Bank of India Act, 1934. Section 54 of the Act has mandated the setting up of the Agricultural credit department to advise the governments at the State and Centre, the State Cooperative Banks and the other banks with regard to the flow of such credit. The Report of the All India Rural Credit Survey published in 1954 however pointed to the various lacuna pertaining to agricultural credit with regard to its quantum and use and inadequate performance of the cooperative banks. Similarly, from time to time developments have taken place which includes the setting up of regional rural banks (RRBs) following the recommendation of Narasimham Committee (1975), establishment of NABARD in 1982 to promote "sustainable and equitable agricultural and rural prosperity" and initiatives like the Kisan Credit Card, SHG-Bank Linkage programme, Kisan Credit card and others.

If we look at the nature of agricultural credit, it can be seen that banks offer different forms of credit to farmers for supporting their agricultural activities. They are in the form of short term credit, medium term credit and long term credit depending on the tenure and purpose of the loan being given. The different institutions like commercial banks, RRBs and cooperative banks play a role in the disbursement of various types of loans so that farmers get the support to adapt latest technology and raise their production and productivity levels. However, the Report of the Internal Working Group to Review Agricultural Credit dated September 13, 2019 raised an alarm regarding the wide regional disparity with regard to the disbursement of agricultural credit. In fact, this is a matter of worry as 72 per cent of the loan requirements are met by institutions and the remaining by the non-institutional sources. The present study therefore makes an effort to find out the possible factors that determine the flow of credit to the different states. The entire manuscript is arranged as follows. Section 2 gives details about the earlier studies. Section 3 mentions the objectives and hypotheses. The next section discusses the research design which is followed by section 5 that gives the results of the analysis. Sections 6 and 7 give details about the conclusions and limitations of the study respectively.

\section{LITERATURE REVIEW}

The researchers make a thorough review of the earlier studies to understand the focus and perspectives of the contributions already made in the area In a few recent studies, the importance of agricultural credit, its position in India and need for change in the policy relating to issue of such credit has been highlighted. D'Souza (2020) notes that despite several measures introduced by the government, agriculture continues to face crisis and one of the key reasons is the inability to access credit from formal institutions. The poor performance is observed in the inability to attain the targets relating to agricultural production. Kumar et al. (2020) finds a close relationship between the access of farmers' households to finance and demographics of the households. In the focus on Eastern states of the country, the researchers find that almost half of the farmers remain excluded from the formal financial system. The study suggests the need to have a better and effective inclusive system so that the maximum number of small/marginal farmers get included in the system. Naveen et al. (2020) in an interesting investigation looks into the effect of issue of Kisan Credit cards on the access to agricultural credit. The overall growth between 1977 and the next four decades is $18 \%$. The share of commercial banks in the issue of agricultural credit is much higher than the cooperative and regional rural banks. Thaque (2020) in a separate study looks into the role of institutional 
funding on the overall economic and productivity of the households. The nature of credit facilities available to such farmers' households has a direct effect on productivity and use of inputs. The overall position of credit draws a very shabby picture mainly in the north-eastern and eastern part of the country in respect of use of institutional credit and regional variation. Yadunandana and Kotreshwar (2018) appreciates the role of agricultural sector despite its declining number in respect of its contribution to the country's GDP. They note that the two key factors hampering the growth of the sector are the high level of indebtedness of the farmers' households with informal money lenders and microfinance institutions. In spite of several efforts made by the government, the agricultural sector has not got the necessary boost required to contribute more to the economic growth. Kumar et al. (2017) looks into the Eastern region of the country and finds that access to agricultural loans from formal institutions has a positive impact on the well-being of the households. Hence, there is a need to develop credit policies which are adaptable and farmer-friendly in nature.. Rant et al. (2018) observe the inequality in both short-term and mediumterm credit flow in Maharashtra as evident from the measures like coefficient of variation, gini coefficient and Theil entropy index. Ganesan (2016) stresses on agricultural credit as it directly impacts production and generation of exportable surplus of the country. The researcher also cites that the credit needs in India show an upward trend because of the developments in science and technology and availability of better seeds, fertilizers and other allied products for a better and healthier agricultural produce. The vital role played by the agricultural sector has been emphasized by Salami and Arawomo (2013) in terms of its ability to generate food, create employment and earn foreign exchange for Africa. However, the study points to the active role played by informal moneylenders in providing finance to farmers. Mann and Kumar (2013) also mention about the contribution of agricultural sector in generation of employment and income from exports and increase in income. In a similar tone, it is seen that agricultural finance plays an important role as it helps farmers to own basic assets (Salami and Arawomo, 2013), get hold on necessary inputs for agriculture (Oluwasanmi and Alao, 1965), technology transfer (Oyatoye, 1981) and increase productivity (Jekayinfa, 1981; Abalu et al, 1981).

Kumar et al. (2010) highlight the concept of Green Revolution in India which was pioneered by M.S.Swaminathan in the 1960s which gave rise to a spurt in the demand for inputs thereby leading to a jump in agricultural production. The authors cite the important role of commercial banks, cooperative banks and RRBs. Kumar et al. (2007) mention data from the RBI to show the share of cooperative banks, RRBs and commercial banks in agricultural credit during the last four decades. Kumar et al. (2007) point to the exploitation of rural farmers in the hands of local money lenders when they charge an interest rate in the range of $36 \%$ to $120 \%$ per annum.

In the researches that cover the sector and agricultural credit, there are several ones which highlight the problems that act as constraint to the developments of the sector. The quandaries faced by the agricultural sector in Africa are cited in the studies of Ansari et al. (2009) and Salami et al. (2010) where they cite low investment and financing as the key factors that result in farmers with small land holdings continuing to remain poor due to low harvest. Khan (1981) points to political interference as an issue in credit disbursement to agricultural sector. Anjoum (1973) in a Pakistan-based investigation finds the insufficient flow of credit towards the agriculture sector in Peshawar by the Agricultural bank of Pakistan. The rural households find it difficult to access finance from formal institutions even in the case of agricultural loan. The government has been taking measures to ensure that credit flows for the benefit of the agricultural sector and hence there is a slow shift from the cooperative banks to the commercial banks (Thejeswini et al., 2014). Mohan (2004) also highlights the loopholes in the flow of agricultural credit which include insufficient flow to the marginal and small farmers and limited flow of funds to the sector that forces farmers to depend on the informal lenders. The researcher calls for the need to have viable and agriculture focused financing institutions. Kumar and Gambhir (2012) mention high interest rate and over-dependence on informal lenders as the key problems for farmers. The first two decades have seen rapid strides with regard to reforms to 
channelize agricultural credit in a better way (Thejeswini et al., 2014). Institutional innovation has happened since 2007-08 to make agricultural financing more directed and productive. Institutional reforms and packages have been offered to cooperative banks and regional rural banks which has resulted in a declining percentage in the share of moneylenders in rural financing (Thejeswini et al., 2014).

On must note that agriculture financing is an important factor that influences rural development (Shraddha, 2013). The issues of agricultural finance have received the attention of policymakers at the international level (Hollinger, 2014). Idress and Ibrahim (1993) in their examination of the role of agricultural credit observe a direct impact of income of farmer households and their attitude towards adopting new farm technologies in Kark district. The study also reveals diverse money-saving behaviour which is due to different levels of education. They observe that farmers adopt modern inputs in terms of technologies, seeds and fertilizers after being granted credit. There are several rural activities which are seasonal in nature and therefore lead to fluctuating cash flows. Hence, rural financing is very important for the sustenance of these activities of which agriculture is an important one (Hollinger, 2014). Gandhimati (2012) elaborates the role played by cooperative banks in agriculture financing. Ahangar et al. (2012) take a look at the loan support provided by scheduled commercial banks for the promotion of agriculture. Anka (1992) observes the historical perspective of agriculture credit in Pakistan and discusses credit policy, loan sanctioning procedure and the factors that affect loan repayment. The author mentions the need to have disbursement of planned credit for agricultural development. Himayatullah (1995) in the examination of growth in institutional credit in Pakistan finds growth rate of more than five percent during 1980 to 1995. The positive aspect in agricultural credit is the adoption of new credit policies to increase the credit flow to the overall agricultural sector and small farmers in particular. However, the researcher observes discrimination with respect to the flow in institutional agricultural credit flow towards different category of farmers and hence calls for the need to restructure and revitalize the system of credit flow to provide benefit to the majority of them.. Sharma and Rani (2016) identify technological constraint as a key issue in the field of agriculture among farmers in Punjab which affects the flow of agricultural credit. They observe a rising trend in flow of credit during the post-reforms period with the share of direct short and long term credit showing a rise during the study period. The other key concerns are in the areas of regulations, investment lacunae, logistics and credit flow mechanism. Matkar and Jadhao (2015) examine the status and problems of agricultural credit in India which acts as serious impediments in economic growth as more than fifty percent of the population is engaged in the agricultural sector. The main problems hover around inadequate credit delivery to the agriculture sector, slow innovation in product design and fast pace of technological challenge. The study by Dar (2015) looks at the flow of agricultural credit in India since the economic reforms took place in 1991. The investigator points to an increasing flow of funds from institutions towards agricultural financing with RRBs showing the maximum growth followed by Scheduled Commercial Banks. The flow to states shows a wide disparity with the maximum flow going to the states of Haryana, Kerala and Punjab. Moreover, there is an increase in flow to farmers having large or medium-sized land holdings. The study, however, notes an under-performance by the agricultural sector compared to the overall economy. In the research contribution by Giri (2015), the key issues that are pointed out include poor credit delivery mechanism, slow processing of loans at the branch level and insufficient flow of funds. Das et al. (2015) mention the positive effect of agricultural credit on farmers' output but also look at poor deposit mobilization and heavy dependence on external funds that has a negative effect on curtailing the flow of agricultural credit. Hoda and Terway (2015) in the analysis of agricultural credit policy in India from 1952 to 2012 appreciate the wide development of financial institutions over time that has led to an increase in disbursement of agricultural credit but at the same time warn about the heavy dependence on money lenders due to declining importance of cooperative banks. Moreover, the interest rate on credit for agricultural purposes needs to be lowered as the short-term credit cost shows a higher proportion of the input cost. Seena (2015) acknowledges the role of agricultural credit in India and effect of banking sector reforms on the agricultural sector. The researcher also scrutinizes the role of cooperative banks and regional rural banks in the Kisan credit card scheme. Vallaserri (2015) 
in the exploration of the trend in flow of agricultural credit for the period 1971 to 2011 looks at the developments in priority lending and financing of agriculture. Godara et al. (2014) look into the concerns of rural financing and find poor quality assets for banks, poor recovery record, and biasedness of banks towards lending as the key issues. Dankwa and Badu (2013) look at the different models following which banks take decisions about whether to lend or not. The discussion mainly hovers around the CAMPARI model, credit scoring model and five Cs model. Ramkumar and Chavan (2013) observe a substantial increase in the share of agriculture credit outstanding from urban and metropolitan branches and also appreciate the role of urban bank branches of West Bengal, Maharashtra and Tamil Nadu. Mohan (2012) looks into the status, issues and future agenda of agricultural credit. This literature discusses the aspects of social banking and changing composition of the formal and informal sector to the financing requirement. The banker also brings to light the important changes that reforms have brought into the industry. Some of them include development in terms of prudential norms, provisioning requirements, kisan credit cards, cap on interest rates on such loans and others. Soni and Saluja (2012) introspect into the role of co-operative banks in meeting the needs of agricultural financing in Chhattisgarh district. The primary data-based study finds an overall satisfaction among respondents towards the disbursement of agricultural credit. However, they point to the issues of inadequate number of branches, poor lending policy and poor customer handling. Gupta and Jain (2012) in another primary data based study point to an overall satisfaction with the lending practices and financial health of cooperative banks in India. Kumar et al. (2010) in the household level research identify the factors that affect flow of agricultural credit. The study discusses the development of formal institutions apart from a specific flow to the agricultural sector from the scheduled commercial banks, RRBs and cooperative banks. It interestingly finds a significant impact of all demographic explanatory variables on the quantum of agricultural credit using tobit regression. Shukla et al. (2012) examines the share of term credit in agriculture by commercial banks and also finds the disparities across different states. The researchers express the need to increase credit flow to meet the infrastructural needs. Das et al. (2009) in a similar econometric based study find the positive impact of direct agricultural credit on agriculture output. Awasti (2007) in the two decadal study from 1981-82 to 2000-01 points to a declining trend in the investment production credit ratio from the average after 1995-96 which is not a positive development for the growth of agriculture in the country. Himayatullah (1995) observes discrimination in Pakistan with respect to the flow in institutional agricultural credit flow towards different category of farmers.

\section{RESEARCH GAP}

The literature review looks at the numerous studies that have been carried out in India and other countries. Researchers have made a query into the role of agricultural credit and its impact on the agricultural sector and its effect on the economy. The role of both formal and informal sector has also been pointed out. There are also several studies that highlight the contribution of the agricultural sector in employment, raise income and earn foreign exchange. In the Indian context, it is true that various academic contributions have been made. Some of them look at the challenges to the agricultural sector and flow of credit. There are papers that look into the issue of agricultural credit and talk about their inadequacy in supply which put the farmers on the backfoot and does not enable them to adopt the modern inputs in agriculture and create impediments for them. There are also research contributions that look into the developments in the agricultural credit policy. With regard to exploratory studies, only a handful exists that are mainly household-based studies which identify the demographic variables which have an effect on the demand for agricultural credit. There is a study by Shukla et al. (2012) which looks into the disparities of flow. The study by Sinha and Kundu (2018) looks into the trend but the application of linear equation fails to capture the quadratic nature of the curve which is captured in this study. However, there is no such statelevel study which identifies factors that affect the flow of agricultural credit. Thus, the present study is not only a methodological improvement over previous studies but also works on an area which has not been looked in earlier academic contributions. 


\section{OBJECTIVES OF THE STUDY}

The manifold objectives of this study are as follows:

i. To look into the trend in flow of agricultural credit.

ii. To identify the key explanatory variables that affect flow of credit to states

\section{HYPOTHESES OF THE STUDY}

In line with the objectives, the following are the hypotheses of this study:

i. $\mathrm{H}_{01}$ : There is no effect of time on flow of agricultural loans.

ii. $\mathrm{H}_{02}$ : There is no significant effect of explanatory variables on flow of agricultural credit to states.

\section{RESEARCH DESIGN}

In any research, design forms a key element as it lays the foundation on which the appropriateness and robustness of the results are based. In line with the objectives of this analysis, the design has the following components:

- Nature and source of data: The present study is made on secondary data collected from the website of Reserve Bank of India. The researchers gather data on credit for the six regions of India which include Northern (NR), North-Eastern (NER), Eastern (ER), Central (CR), Western (WR) and Southern (SR).

- Data period: The investigation uses data for a period of eleven years from 2007 to 2017.

- Research methods used: The researchers use statistical tools to arrive at the results. In order to know the growth rate, semi-log quadratic trend equation is fitted.

The equation is $\ln \left(Y_{t}\right)=\alpha+\beta_{1} t+\beta_{2} \cdot t^{2}$, where $Y_{t}$ is the dependent variable, $t$ is time and $\beta_{1}$ and $\beta_{2}$ are coefficients.

Thus, the quadratic form of the curve is tested in the study. Here, $\beta_{1}$ represents the growth rate, whereas $\beta_{2}$ represents the rate of acceleration or deceleration. Both $\beta_{1}$ and $\beta_{2}$ can be positive or negative.

In order to meet the second objective, regression method is applied in which the panel is an unbalanced one due to non-availability of data for some states in some years of the period. Hence, the study involves multi-dimensional data over a period of time which implies the application of panel data which is considered by the investigators to examine the effect over time and also the difference between cross-sectional units.

The following variables are considered.

\section{Description of variables}

- Dependent variable: For the purpose of this paper, to look into the growth in flow of agricultural credit to 
different regions, 'agricultural credit' data that is available from the RBI website is considered as the dependent variable. In the considered model, log transformed value of agricultural credit is considered as the explained variable. Independent variables: In the category of independent variable, there are two sub-categories viz. 'state-specific' independent variables and 'macroeconomic' variables. Under the former, two variables are considered which are (i) share of agriculture in the state gross domestic product and (ii) crop intensity. On the other hand, in the latter category, the variables considered are (i) lending rate (on agricultural loans) and (ii) inflation rate. Hence, the variables are so considered that it will help to identify the effect of factors specific to different states and also broad macro-economic measures.

The following table describes the above-mentioned variables.

Table 1 : Description of variables

\begin{tabular}{|c|c|c|c|}
\hline Variables & $\begin{array}{c}\text { Category of } \\
\text { variable }\end{array}$ & Mnemonics & Variable Explanation \\
\hline $\begin{array}{c}\text { Flow of agricultural } \\
\text { credit to different states }\end{array}$ & Dependent & ln(agr_credit) & $\begin{array}{c}\text { Measure of the flow of } \\
\text { agricultural credit to the } \\
\text { Indian states }\end{array}$ \\
\hline $\begin{array}{c}\text { Importance of } \\
\text { agriculture in the state }\end{array}$ & Independent & agrshare_gdp & $\begin{array}{c}\text { Agricultural GDP of state } \\
\text { divided by the total GDP of } \\
\text { the state }\end{array}$ \\
\hline $\begin{array}{c}\text { The intensity of usage of } \\
\text { agricultural land }\end{array}$ & Independent & crop_intensity & $\begin{array}{c}\text { (Gross cropped area / Net } \\
\text { sown area) x 100 }\end{array}$ \\
\hline $\begin{array}{c}\text { Lending rate } \\
\text { Inflation rate }\end{array}$ & Independent & lending_rate & $\begin{array}{c}\text { Rate of interest on } \\
\text { agricultural loans }\end{array}$ \\
\hline
\end{tabular}

Source: Conceptualized by researchers

In order to have a true reflection of the effect of variables, before the application of panel regression, some basic statistical and econometrical measures are employed which include descriptive statistics (to understand the basic characteristics of data) and variance inflation factor (VIF) to check for multicollinearity.

\section{ANALYSIS AND FINDINGS}

\section{Regional share in agricultural loans}

The section discusses the share of different regions in the agricultural loans disbursed by the commercial banks. 
Table $2: \%$ share of different regions in agricultural credit

\begin{tabular}{|c|c|c|c|c|c|c|c|}
\hline Year & NR & NER & ER & CR & WR & SR & Total \\
\hline $2007-08$ & 22.31 & 0.73 & 8.25 & 17.12 & 17.74 & 33.84 & 100 \\
\hline $2008-09$ & 23.46 & 0.81 & 7.85 & 18.35 & 13.63 & 35.90 & 100 \\
\hline $2009-10$ & 22.60 & 0.85 & 8.48 & 18.12 & 13.66 & 36.29 & 100 \\
\hline $2010-11$ & 22.39 & 0.89 & 8.79 & 16.42 & 12.73 & 38.79 & 100 \\
\hline $2011-12$ & 20.32 & 0.96 & 8.32 & 16.04 & 12.45 & 41.90 & 100 \\
\hline $2012-13$ & 19.38 & 1.11 & 8.52 & 16.09 & 13.79 & 41.11 & 100 \\
\hline $2013-14$ & 20.65 & 1.03 & 8.51 & 16.31 & 12.71 & 40.79 & 100 \\
\hline $2014-15$ & 20.04 & 1.09 & 8.33 & 17.36 & 12.60 & 40.58 & 100 \\
\hline $2015-16$ & 21.66 & 1.37 & 8.81 & 18.54 & 13.93 & 35.69 & 100 \\
\hline $2016-17$ & 20.38 & 1.34 & 8.05 & 18.44 & 13.86 & 37.94 & 100 \\
\hline $2017-18$ & 20.94 & 1.33 & 7.91 & 17.39 & 12.56 & 39.87 & 100 \\
\hline
\end{tabular}

Source: Computed by researchers

The descriptive statistics on the basis of regional share of agricultural loans shows that the southern, northern and central regions enjoy the maximum share and command a combined mean share of around 80 per cent. The measures of skewness and kurtosis give an idea about the distribution of data over the years with respect to symmetry and peakedness respectively.

Table 3 : Descriptive statistics based on share of regions

\begin{tabular}{|c|c|c|c|c|c|c|}
\hline Measure & NR & NER & ER & CR & WR & SR \\
\hline Mean & 21.28 & 1.05 & 8.35 & 17.29 & 13.61 & 38.43 \\
\hline Kurtosis & -1.05 & -1.27 & -0.80 & -1.72 & 6.79 & -1.24 \\
\hline Skewness & 0.25 & 0.28 & -0.14 & 0.00 & 2.41 & -0.36 \\
\hline Minimum & 19.38 & 0.73 & 7.85 & 16.04 & 12.45 & 33.84 \\
\hline Maximum & 23.46 & 1.37 & 8.81 & 18.54 & 17.74 & 41.90 \\
\hline
\end{tabular}

Source: Computed by researchers 


\section{Disparity in flow of credit across regions}

In this section, the researchers find out the extent of disparity in the flow of loans to the different regions of the country. For the purpose, the Gini coefficient is computed. The result for all the years shows that the inequality has been quite high with the minimum and maximum values being 34.727 in 2007 and 40.711 in 2011 respectively. In fact, there has been no major change in the level of disparity during the period.

Table 4 : Disparity in flow of agricultural credit

\begin{tabular}{|c|c|c|c|}
\hline Year & Gini & Year & Gini \\
\hline $2007-08$ & 34.727 & $2013-14$ & 39.804 \\
\hline $2008-09$ & 37.83 & $2014-15$ & 39.557 \\
\hline $2009-10$ & 37.34 & $2015-16$ & 35.794 \\
\hline $2010-11$ & 38.995 & $2016-17$ & 37.433 \\
\hline $2011-12$ & 40.711 & $2017-18$ & 39.446 \\
\hline $2012-13$ & 39.147 & & \\
\hline
\end{tabular}

Source: Sinha and Kundu (2018)

\section{Growth rate in credit in different regions}

In this section, the result of the fitted semi-log quadratic growth trend line equation is discussed.

Table 5 : Growth rate of agricultural credit in different regions

\begin{tabular}{|c|c|c|c|c|}
\hline Region & $\mathrm{R}^{2}$ & F-stat. & $\beta_{1}$ & $\beta_{2}$ \\
\hline Northern & 99.4 & $652.287^{* * *}$ & $0.199^{* * *}$ & $-0.005^{* * *}$ \\
\hline North-Eastern & 99.6 & $1058.767^{* * *}$ & $0.321^{* * *}$ & $-0.009^{* * *}$ \\
\hline Eastern & 99.1 & $459.210^{* * *}$ & $0.275^{* * *}$ & $-0.010^{* * *}$ \\
\hline Central & 99.4 & $629.645^{* * *}$ & $0.208^{* * *}$ & $-0.004^{* *}$ \\
\hline Western & 96.3 & $103.081^{* * *}$ & $0.159^{* * *}$ & -0.002 \\
\hline Southern & 98.4 & $249.096^{* * *}$ & $0.311^{* * *}$ & $-0.012^{* * *}$ \\
\hline Total & 97.5 & $350.850^{* * *}$ & $0.244^{* * *}$ & $-0.008^{* * *}$ \\
\hline
\end{tabular}

Source: Computed by researchers

***significant at $1 \%$ level, **significant at $5 \%$ level

Note: The above trend is arrived at using semi-log quadratic equation 
Here, $\beta_{1}$ represents the growth rate, whereas $\beta_{2}$ is the acceleration/deceleration rate.

The above table shows that the model is a good fit as evident from the value of R-squared. The explanatory power of time (as evident from R-squared) in describing the variation in the flow of credit to different regions is more than $96 \%$ in all the cases. Hence, the quadratic equation that is fitted for computing the growth rate fits perfectly in the case of all the six regions and India as a whole. A noticeable point regarding the equation of the trend curve is that it is quadratic in nature with a rise initially (as evident from the positive coefficient of $\beta_{1}$ in all the cases) which is followed by a decline in the growth rate (as seen from the negative coefficient of $\beta_{2}$ ). With respect to the growth, computations show that it is quite high for all the regions with North-East, South and East showing growth rates of $32.1 \%, 31.1 \%$ and $27.5 \%$ respectively. An interesting point in all the regions is that though the trend shows a decline, the rate of fall is very low (ranging between $0.2 \%$ and $1.2 \%$ ) compared to the rise. Thus, though the curve shows an inverted U-shaped curve, the rate of change in the decline is very low in contrast to the sharp rise. Hence, though the overall curve shows an upward trend, the rate of increase declines over time.

\subsection{Factors affecting flow of credit}

This section of the study presents the result of panel regression which is applied to identify the key influencing variables among the state-specific and macroeconomic levels.

\subsubsection{Model Specification}

In this study, the assumption is that the states are likely to have characteristics that are unique to it and has an influence on the predictor variables. Hence, these time-invariant characteristics should be removed before running the regression due to which the fixed effect model is applied. However, the final choice of the model is also cross-checked with the application of the Restricted F-test, Breusch-Pagan test and Hausman test.

For a fixed effect model, the general equation takes the following form:

$$
\mathrm{y}_{\mathrm{it}}=\alpha_{\mathrm{i}}+\mathrm{x}_{0 \mathrm{it}} \beta+\mathrm{u}_{\mathrm{it}}
$$

where $\alpha_{\mathrm{i}}$ are the individual intercepts which is assumed to be fixed for the ' $\mathrm{N}$ ' number of cross-sectional units.

The basic econometric model for this study has the following formulation:

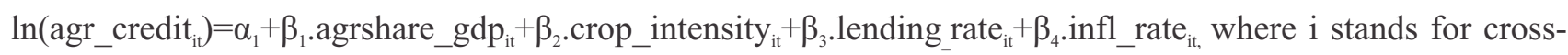
sectional units and $t$ for time.

\section{Testing for multi-collinearity}

- In Stata, by using the 'estat' command, the values of variance inflation factor for the independent variables are derived. 
Table 6 : Result for multicollinearity

\begin{tabular}{|c|c|c|}
\hline Variable & VIF & Tolerance \\
\hline agrshare_gdp & 1.66 & 0.60 \\
\hline infl_rate & 1.42 & 0.70 \\
\hline lending_rate & 1.24 & 0.80 \\
\hline crop_intensity & 1.02 & 0.98 \\
\hline Mean VIF & 1.33 & - \\
\hline
\end{tabular}

Source: Computed by researchers

It is evident from the above table that the VIF of all the variables is less than 5 and hence there is no multicollinearity problem. Next, we test for heteroscedasticity which is a common problem in cross-sectional data and hence also in panel data. The 'hettest' command gives result of the test using the Breusch-Pagan / Cook-Weisberg test. tThe chi-squared statistic value is found to be 15.01 (with a p-value of 0.0001 ). Thus, the null hypothesis of constant variance is rejected at $1 \%$ level. Hence, for rectification of the problem in the data, after the use of the basic model, the 'robust' command is used for panel regression.

\section{Testing of the model}

The basic econometric model for the study takes the following form as given below:

\section{Model design:}

Here, the log tranformed value of agricultural credit is the dependent variable. The equation is:

$$
\ln \left(\operatorname{agr} \_ \text {credit }_{\mathrm{it}}\right)=\alpha_{1}+\beta_{1} \cdot \text { agrshare_gdp } \mathrm{it}_{\mathrm{it}}+\beta_{2} \cdot \mathrm{crop} \_ \text {intensity }{ }_{\mathrm{it}}+\beta_{3} \text {.lending } \text { rate }_{\mathrm{it}}+\beta_{4} \cdot \text { infl_rate }_{\mathrm{it}}
$$

The results of regression are given below. Initially, the researchers aim to determine which one is relatively a more appropriate one - pooled OLS or the fixed effect model. The result shows that in the Restricted F Test, F $(28,200)$ test statistic value is 178.23 which is significant at $1 \%$ level, thereby providing support for the fixed effect (FE) model as it rejects the null hypothesis. In the Breusch - Pagan Lagrange Multiplier Test, the value of $\chi 2$ (4) is 155.69 which is also significant at $1 \%$ level, thereby supporting the random effect (RE) model. Hence, the Hausman test is applied to finalize between the FE and RE models. The Hausman Test statistic $\left[\chi^{2}(4)=24.56^{*}\right]$ is observed to be significant (at $1 \%$ level) thereby rejecting the null hypothesis of non-systematic difference in coefficients. Thus, the FE model is found to be most fitting model in the present study. Hence, the result of FE model (corrected for heteroscedasticity problem) is given below. 
Table 7: Result of panel regression

\begin{tabular}{|c|c|c|c|c|}
\hline Variable & \multicolumn{2}{|c|}{ Robust FE model (accepted model) } & \multicolumn{2}{|c|}{ Robust RE model } \\
\hline Variable & Coefficient & t-stat & Coefficient & Z-stat. \\
\hline Intercept & 7.2048 & 23.03 & 7.0899 & 17.24 \\
\hline Crop_intensity & $0.0002 * * *$ & 2.48 & $0.0002 * * *$ & 2.60 \\
\hline Agrshare_gdp & 0.0082 & 0.85 & 0.0111 & 1.09 \\
\hline Lending_rate & $(0.2396)^{* * *}$ & $(12.51)$ & $(0.2333)^{* * *}$ & $(12.13)$ \\
\hline Infl_rate & $(0.0880) * * *$ & $(9.84)$ & $(0.0843)^{* * *}$ & $(9.17)$ \\
\hline \multicolumn{5}{|c|}{ Model details } \\
\hline Wald- $\chi 2$ / F stat & 100.32 & - & 395.66 & - \\
\hline $\mathrm{R}^{2}-\mathrm{Within} / \mathrm{R}^{2}$ & 0.4487 & - & 0.4484 & \\
\hline $\mathrm{R}^{2}$ - Between & 0.0595 & - & 0.0885 & \\
\hline $\mathrm{R}^{2}$ - Overall & 0.0452 & - & 0.0521 & \\
\hline
\end{tabular}

Source: Computed by researchers

*** significant at $1 \%$ level, ${ }^{* *}$ significant at $5 \%$ level, * significant at $10 \%$ level,

The result of panel regression is interesting. The effect of the variables with respect to sign do not deviate from the expected result. In other words, the variables relating to cropping intensity and importance of agriculture in the state exhibit positive effect in the regression result, whereas lending rate and inflation rate have a negative effect. Moreover, the effect of cropping intensity, lending rate and inflation rate are found to be significant at $1 \%$ level. However, though the share of agriculture in the state GDP matches the expected sign, the coefficient is not significant even at $10 \%$. Thus, the findings hold immense relevance as it identifies the factors that decide the increase or decrease in flow of agricultural loans. A noticeable point is the fall in loans due to rise in lending rate on agricultural credit. Hence, there is a reduction in the flow to the states and same is the interpretation with inflation rate. Thus, in a country like India where agriculture is a major source of activity for more than $70 \%$ of the households, it is necessary to keep the interest rate low (by giving higher subsidy) so that it does not have an impact on agricultural production and productivity. The extent of usage of the agricultural land which is proxied using cropping intensity has a positive impact on flow of agricultural loans. With rising prices (proxied by inflation rate), the price of commodities (all forms of agricultural inputs) increase due to which it is evident that agricultural farmers curtail their propensity to take loans. This is likely to affect the production levels and increase the reliability on local level money-lenders. Hence, the study brings out very important conclusions that hold wide relevance in respect of the Indian economy in which majority of the households still rely on agriculture and farming activities. 


\section{CONCLUSIONS}

The study focuses on the agricultural sector in India with special attention on the agricultural credit flow to the different regions and states. The issue is of immense relevance in the country where even today almost $55 \%$ of the populace is engaged in some form of employment and where agriculture contributes around $15 \%$ to the country's gross domestic product. Though, the agricultural activity in the country contributes substantially in monetary terms, there are various issues that the sector is confronted with which include inadequate support to the farmers in respect of loans, falling contribution of cooperative banks, huge reliance on informal money lenders for financial support which have been highlighted in the review of past studies. The analysis of distribution of agricultural credit on an all-India basis shows a clear biasedness towards certain regions and a sign of apathy towards other selected regions. In specific terms, the Southern, Northern and Western regions attract almost fourfifth of the total agricultural credit that is disbursed by the commercial banks. The most neglected region is the north-east which has attracted an average of only $1 \%$ during the study period. The measure of Gini coefficient shows a wide disparity across regions which has remained near the same level during the period. The researchers also look at the issue of growth in flow of credit to the regions. The interesting point is that the trend follows the shape of a parabola with a rise during the initial years but a slowing rate of growth towards the end of the study period. The most important aspect that the investigators look into is the identification of factors that have an impact on the flow of agricultural credit to the different states. The analysis shows that the most important statelevel factor is cropping intensity (extent of usage of arable land) but the importance of agriculture plays a less important role which has been also pointed by the RBI. With regard to the macro-economic variables, interest rate and inflation rate has a negative effect on credit flow. Thus, the empirical study highlights the different developments by using the approaches of descriptive research and causal research. Definitely, the findings are an eye-opener for the government and will help to determine ways by which the extent of equity in distribution can be increased during the years. This is a real challenge for policy-makers and bankers as without the adequate support from these financial institutions, the farmers' households are forced to remain in abject poverty and the dream of inclusive growth can never be fulfilled.

\section{LIMITATIONS OFTHE STUDY}

The study is very relevant in the context of India where disparity and non-inclusive growth is a problem. The research has been done with an approach to arrive at robust results but still it suffers from some limitations. As already mentioned, the RBI website does not provide data for all states, due to which the analysis is done on an unbalanced panel. Moreover, for the determination of key factors, non-financial state-specific factors are not considered and it can form the scope of another study.

\section{REFERENCES}

Abalu, G.O.., Famoriyo. S., \& Abudullahi, Y.A. (1981). Production problems in Nigeria: an overview. In Edordu et al. (eds.), Agriculture Credit and finance In Nigeria: Problems and Prospects, Central Bank of Nigeria. April.

Ahanger, G.B., Gaine, A.H., \& Padder, M.J. (2012). A study on institutional Credit to agricultural sector in India. International Journal of Current Research and Academic Review, 1(4), 72-80.

Anjani, K., Singh, K.M., \& Shradhajali, S. (2010) Institutional credit to agriculture sector in India: Status, performance and determinants. Agricultural Economics Research Review, 23, 253-264.

Anka, A.M. (1992). Analytical report on supervised agricultural credit: Its problems, prospects and suggestions 
for implementation in Pakistan. Journal of Rural Development and Administration, 24(1), 137-147.

Awasthi, A. (2007).Production and Investment credit of scheduled commercial banks in India. International Journal of Agriculture Economics, 62(3), 314-320.

Dankwa, I., \& Badu, G. (2013). Principles and practice of lending in the banking sector: A case study of some selected banks in Ghana. Journal of contemporary Integrative ideas, 1(2), 9-21.

Dar, J. (2015). Trends and Growth of flow of credit to Agriculture after1991 in India. Journal of Humanities and Social Sciences, 20(1), 51-61.

Das, A., Senapati, M., \& John, J. (2009). Impact of agriculture credit on agriculture production, Reserve Bank of India, Occasional Paper, 30(2).

D'Souza, R. (2020). Improving access to agricultural credit: New Perspectives. ORF Occasional Paper No. 230, $1-46$.

Gandhimathi, S. (2012). Distribution of agricultural credit in the pre and post reform period. International Journal of Management, IT and Engineering, 2 (9), 243-253.

Ganesan, S. (2016). Development of agricultural credit in India. Shanlax International Journal of Commerce, 4(3), July, 194-201.

Giri, P. (2015). Agriculture credit in India. International Journal of Science Technology, 4(7), 98-106.

Gupta, J., \& Jain, S. (2012). A study on Cooperative Banks in India with special reference to Lending Practices. International Journal of Scientific and Research Publications, 2(10), 1-6. Hoda, A., \& Terway, P. (2015). Credit Policy for Agriculture in India - An Evaluation. Indian Council For Research On International Economic Relations, Working Paper 302, June.

Hollinger, F. (2014). Agricultural Finance - Trends, Issues and Challenges. giz Financial Development Systems, $1-60$.

Khan, H. (1995). Agricultural credit availability and requirement in Pakistan: A detailed analysis. Journal of Rural Development and Administration, 27(4), 67-76.

Idress, M., \& Ibrahim, M. (1993). Agricultural credit role in the development of agriculture. Journal of Rural Development and Administration, 25(4), 64-74.

Jekayinfa, S. (1981). Agricultural Credit in South East Asia, Development, 27, 55-66.

Kumar, K. (2013). Financing to weaker section by commercial banks in India: Problem and Prospect. International Journal of Research in IT and Management, 3(1), 69-77.

Kumar, A., Singh, K.M., \& Sinha, S. (2010). Institutional Credit to Agriculture Sector in India: Status, Performance and Determinants. Agricultural Economics Research Review, 23, July-December, 253-264.

Kumar, A., Singh, D.K., \& Kumar, P. (2007). Performance of rural credit and factors affecting the choice of credit sources. Indian Journal of Agricultural Economics, 62(3), 297-313.

Kumar, A., Mishra, A., Saroj,, S.\& Joshi, P.K. (2017). Institutional versus non-institutional credit to agricultural households in India: Evidence on impact from a National Farmers' Survey. Economic Systems, 28(3), 197213.

Kumar, A., Das, R., Bathla, A.K.S., \& Jha, G.K.. (2020). Examining institutional credit access among agricultural households in Eastern India: Trends, Patterns and determinants. Agricultural Finance Review, Advance online publication. doi:10.1108/AFR-04-2020-0054.

Maan, V.K., \& Kaur, B. (2013). Factor affecting distribution of agricultural credit. International Journal of Emerging Trends \& Technology in Computer Science, 2(2), 7-13.

Matkar, S., \& Jadhao, A. (2015). Agriculture credit in India-status and challenges. Research Report, 2(2), 125132. 
Mohan, R. (2004). Agricultural credit in India: Status, Issues and future Agenda. Reserve Bank of India Bulletin. Retrived from http://www.rakeshmohan.com/docs/AgricreditBulletin.pdf.

Naveen, N., Senthilkumar, R., Rajendran, T. \& Selvi, R.G. (2020). Growth of agricultural credit in India: Before and after introduction of Kisan credit cards. International Journal of Current Microbiology and Applied Sciences, 9(9), 2593-2601.

Oluwasanmi, H.A. \& Alao, J.A. (1965). The Role of Credit in the Transformation of Traditional Agriculture: The Western Nigeria Experience. The Nigerian Journal Of Economic and Social Studies, 7(1), 31-50.

Oyatoye, E.T.O. (1981). Financing small farmers. A change of strategy. In Edordu et al. (Ed). Agricultural credit and finance in Nigeria: Problems and prospects. Central Bank of Nigeria. April.

Ramkumar, R., \& Chavan, P. (2013). Bank credit to Agriculture in India in the 2000s. Review of Agrarian Studies, 4(1), 51-79.

Rant, S., Wadkar, J., \& Talathi, J. (2018). Regional inequality in medium-term credit flow by DCCBs in Maharashtra. International Journal of Microbiology and Applied Sciences, 7(1), 2589-2598.

Sharma, S., \& Rani, V. (2016). Agriculture credit in Punjab: Issues, Concerns and Measures. International Journal of Business Quantitative Economics and Applied Management Research, 2(10), 229-245.

Seena, P.C. (2015). Management of Agriculture credit and the impact of Indian Banking sector reforms on agriculture. International review of Research in emerging market and the global economy, 1(3), 378-391.

Shraddha, S. (2013). Financial innovation in Indian agricultural credit market: Progress and performance of Kisan Credit Card. International Journal of Ongoing Research in Management and Information Technology, 13, 13.

Shukla, A., \& Tiwari, S. (2012). Analysis of status and trends of investment credit in Indian Agriculture. Journal of Agriculture Science, 3(1), 29-33.

Sinha, A., \& Kundu, D. (2018). Region-Based Analysis Of Agricultural Credit By Scheduled Commercial Banks In India: A Critical Review. Uttaranchal Business Review, 8(2), December, 75-88. Retrieved from https://uuimg.s3.ap-south-1.amazonaws.com/2019/07/UIM_Journal_2019_XPS1005191768.pdf

Thaque (2020, September 24). Regional inequality in the flow of institutional credit to agriculture. Hindkisan. Retrieved from https://www.hindkisan.com/hind-kisan-in-english/regional-inequality-in-the-flow-ofinstitutional-credit-to-agriculture/21254/, accessed on December 5, 2020.

Thejeswini, R., Kiresur, V.R., Preeti, N.S., Teggy, M,Y \& Trilokanatha, G.A. (2014). Agricultural Credit in IndiaInnovations in Design and Delivery of Products and Services, Agricultural Economics Research Review, 27, 75-83, DOI: 10.5958/0974-0279.2014.00009.3.

Yadunandana, H.C. \& Kotreshwar, G. (2018). Trends in agricultural credit. International Journal of Engineering and Management Research, 8(6), 201-205. 
